\title{
The Modeled Effects of Rice Field Idling on Groundwater Storage in California's Sacramento Valley
}

\author{
Kevin Anderson', Eric Houk², Steffen Mehl³, David L. Brown ${ }^{4}$ \\ ${ }^{1}$ Graduate Student, Geological and Environmental Sciences, California State University, Chico, CA, USA \\ ${ }^{2}$ College of Agriculture, California State University, Chico, CA, USA \\ ${ }^{3}$ Department of Civil Engineering, California State University, Chico, CA, USA \\ ${ }^{4}$ Geological and Environmental Sciences Department, California State University, Chico, CA, USA \\ Email: ehouk@csuchico.edu
}

How to cite this paper: Anderson, K., Houk, E., Mehl, S. and Brown, D.L. (2017) The Modeled Effects of Rice Field Idling on Groundwater Storage in California's Sacramento Valley. Journal of Water Resource and Protection, 9, 786-798.

https://doi.org/10.4236/jwarp.2017.97052

Received: May 6, 2017

Accepted: June 13, 2017

Published: June 19, 2017

Copyright (c) 2017 by authors and Scientific Research Publishing Inc. This work is licensed under the Creative Commons Attribution International License (CC BY 4.0).

http://creativecommons.org/licenses/by/4.0/

\begin{abstract}
Rice farmers occupy a potentially important intersection between economics and hydrology in Northern California. While drought makes water an increasingly precious commodity across California, the monetary worth of water is not uniform across different localities and uses. As a result, circumstances have given many Sacramento Valley rice farmers the option to sell their water to users elsewhere, in lieu of using it themselves. Because the sold water is typically surface water that would normally help recharge local aquifers when applied to a field; it is reasonable to suspect that transferring that water elsewhere could adversely affect local aquifers since that recharge would be reduced. This study performs numerical experiments using the United States Geological Survey's Central Valley Hydrologic Model (CVHM) to better understand the temporal effects of a set of land idling scenarios. CVHM is capable of modeling the entire Central Valley, which encompasses the Sacramento and San Joaquin Valleys, and of representing rice field idling on a large scale. These experiments were executed using historical data to contrast recently typical amounts of rice field idling with scenarios reflecting varying degrees of hypothetical, increased idling. In doing so, this study aims to characterize the nature and potential magnitude of idling rice fields on groundwater storage in the Sacramento Valley. The impact of these scenarios on groundwater storage was quantified relative to an unaltered baseline model scenario. The results of this research show rice field idling will reduce recharge and groundwater storage levels; these results may provide useful information for future policy decisions and provide a basis for future study.
\end{abstract}

\section{Keywords}

Groundwater, Crop Idling, MODFLOW, Recharge, Sacramento Valley 


\section{Introduction}

The hydrology of the Sacramento Valley is worthy of study largely for its importance to natural and engineered water systems throughout most of California. Precipitation falls disproportionally in Northern California, to flow through the Sacramento Valley to the Sacramento-San Joaquin Delta. Along the way, this water supplies a variety of riparian, wetland and aquatic habitats which support various natural communities and numerous endangered species [1]. Likewise, this water is utilized by humans, not only for the needs of local users, but is diverted by reservoirs, pumps and waterways to supply agricultural, municipal and industrial needs elsewhere in California.

Agricultural water use is the quantitatively greatest of these human needs, and the largely engineered nature of water distribution in California affects the economics of agricultural water use. To the extent that agricultural users can sell and transfer their allocated water, the economic worth of water can vary greatly over time and geographically. For a variety of economic factors, the difference in the price of water between geographically distant users can be especially high when water is scarce. This would seem to be a topical concern, given the predominance of drought conditions in California this decade. If this price difference of water between farmers is high enough, a farmer might choose to sell their allocation of water and idle their field, rather than utilize that water themself.

While perhaps counter-intuitive, such a practice may have an adverse effect on groundwater systems in the area from which the water was transferred. Although idling a field is a passive act, the aquifer may still be affected because not all the water applied to a field is consumed by the crop [2]. The remaining water evaporates, returns to surface water channels, or infiltrates into the ground. Because of the latter, water used in agriculture can be an artificial source of recharge to local aquifers. Consequentially, idling a field removes that source of potential recharge. In terms of the water budget, ceasing to add water that is normally added to the aquifer is functionally the same as removing water from the aquifer.

This study examines the above possibility in the Sacramento Valley, as it pertains to rice farming. Rice is of particular importance to this issue because rice is one of the Sacramento Valley's predominant crops, making up about $23 \%$ of its agricultural acreage [3]. In addition, rice is an annual crop. Unlike orchard crops like walnuts and almonds (which are also common in Northern California), where consistent watering is necessary to protect one's long-term investment in an orchard, a farmer could typically idle a rice field on a given year with relatively less economic consequences. This makes the practice of transferring water and idling fields much more likely among rice farmers, this study seeks to investigate the possible effects of this practice on groundwater storage.

\section{Study Area}

The Sacramento Valley is the northern portion of California's Central Valley, while the San Joaquin Valley makes up the southern portion. Geographically, the 
Central Valley is bound by the Coastal Ranges to the west, Sierra Nevada Mountains to the east, Cascade Mountains to the north, and Tehachapi Mountains to the south [3]. This is a span of about 400 miles $(644 \mathrm{~km})$ length with an average width of about 50 miles $(80 \mathrm{~km}$ ), for an approximate area of about 20,000 square miles $\left(51,800 \mathrm{~km}^{2}\right)$. The Central Valley is unevenly divided with respect to the Sacramento-San Joaquin Delta, into the San Joaquin Valley to the south and the Sacramento Valley to the north. The Sacramento Valley, makes up approximately one-third of the Central Valley's area (Figure 1).

Topographically the Central Valley is characterized by low relief, with most of the valley near sea level, a typical elevation of about 500 feet $(152 \mathrm{~m})$ at its eastern boundary and a typical range of elevations of $50-350$ feet $(15-107 \mathrm{~m})$ at its western boundary [3]. Climate ranges from arid to Mediterranean, with hot, dry summers and cool, wet winters. Variations in the typical climate occur as droughts and floods. Average yearly precipitation ranges from 46 inches (116.8 $\mathrm{cm})$ in the extreme north of the valley to 5 inches $(12.7 \mathrm{~cm})$ in much of the south [3]. Evapotranspiration varies less dramatically, from 45 inches $(114.3 \mathrm{~cm})$ to the

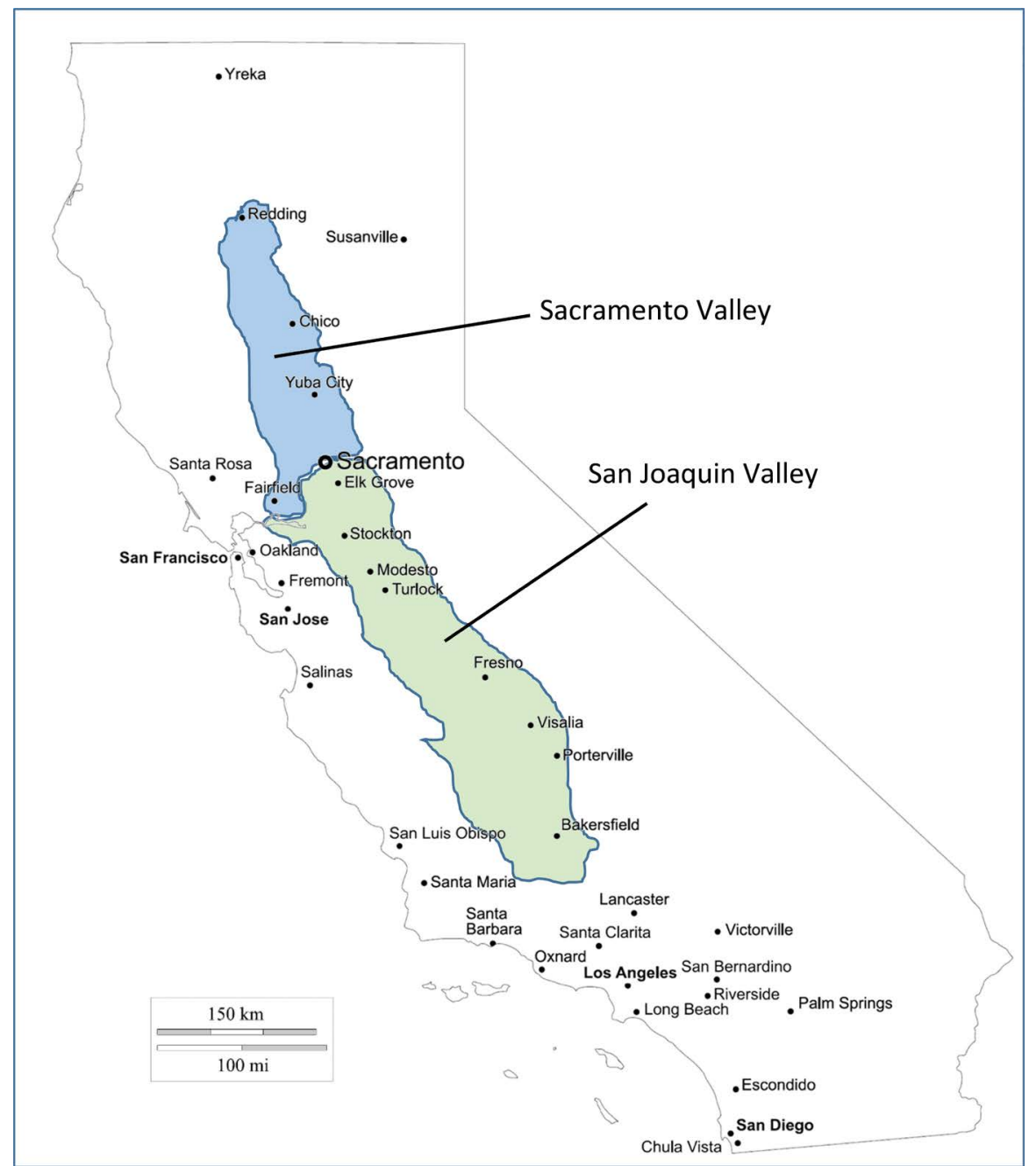

Figure 1. California's Central Valley highlighted with Sacramento Valley in blue and San Joaquin Valley in green. 
north to 56 inches $(142.2 \mathrm{~cm})$ to the south, and generally increases from north to south [3].

Geologically the Central Valley is a large basin filled in with Jurassic to Holocene sediments, forming multiple strata of alluvial and fluvial sediments sourced from the neighboring mountain ranges [3]. Though the depth of these sediments can be as much as 6 miles $(9.7 \mathrm{~km})$ deep in the Sacramento Valley, sediment bearing freshwater is generally limited to a depth of 1000 to 3000 feet (305 to 914 $\mathrm{m})$. Sediments in this aquifer system are typically unconsolidated or semiconsolidated, with grain sizes ranging from clay to gravel.

As California developed, its water problems were compounded by the geographic difference between where water was relatively abundant (in the north) and where additional development and water was needed (in the south). As a result, systems of water storage and delivery were constructed throughout California to deliver surface water to agricultural, municipal and industrial users [3]. The two most significant of these are the Central Valley Project (CVP), formed in the early $1930 \mathrm{~s}$ by the federal government under supervision of the U.S. Bureau of Reclamation (USBR), and the State Water Project (SWP), formed in the early $1950 \mathrm{~s}$ by the State of California under supervision of California's Department of Water Resources (DWR). Together these projects use natural and engineered waterways to facilitate water transfers throughout the state.

In the case of appropriative surface water rights, water can be transferred with permission of the State Water Resources Control Board, provided that it does not unreasonably injure the rights of other water users, or wildlife [4]. This is particularly common in drought years, providing an additional means of meeting statewide water demands. Water transfers most commonly originate from the Sacramento Valley, and are delivered to the San Joaquin Valley [5].

When a farmer in the Sacramento Valley transfers their water, they may choose to idle their field that year. While the practice of field idling to transfer water has generally been limited to $20 \%$ of a county's total irrigated land [6], the motivation for this is primarily economic, as the regional economies of predominantly agricultural communities may be adversely affected by excessive field idling. It remains to be seen if this $20 \%$ mark is reasonable for managing Sacramento Valley groundwater supplies. It is also worth noting that fields idled as a part of normal agricultural practices are not included in this $20 \%$.

This study limits its discussion to effects of rice field idling. Although walnuts, almonds, and rice are the top three commodities in terms of irrigated acreage and value in the Sacramento Valley [7], rice is the only commodity that would be compatible with single year idling since it is an annual crop. Rice is typically irrigated by flooding the field continuously during the growing period. The efficiency of continuous flood irrigation is variable, but generally lower than pressurized irrigation methods such as those using sprinkler or drip systems. Percolation and seepage can account for $25 \%-50 \%$ of the total water input when rice is grown in fine-grained soils and the groundwater table is very shallow (20 - 50 $\mathrm{cm}$ ), or as much as $50 \%-85 \%$ when soils are course-grained and groundwater 
depth is greater than $1.5 \mathrm{~m}$ [8]. These percentages encompass both percolation (vertical subsurface flow into the aquifer) and seepage (lateral subsurface flow to neighboring fields, waterways, etc.), and measuring these losses separately is difficult. Still, it is reasonable to expect that a significant fraction of the water applied to a rice field will percolate to the water table.

\section{Research Methods and Data}

The Central Valley Hydrologic Model (CVHM) is a regional hydrologic model developed by the United States Geological Survey (USGS) to describe groundwater availability in the Central Valley and was released in 2009 [3]. Since then, CVHM has seen use by the scientific community [9] [10] [11] as well as government agencies [1] [3]. CVHM utilizes the USGS modular three-dimensional finite-difference groundwater flow model, updated in 2000 (MODFLOW-2000 or MF2K) to model the physical surface and subsurface as well as the hydrologic system of the Central Valley [3].

CVHM incorporates a variety of data from 1961 to 2003 related to topology, lithology, hydrology, compaction related to land subsidence, land use, and water deliveries in the Central Valley. This breadth of data allows CVHM to be used to describe the hydrologic system in a variety of ways, relating groundwater flow to land use, groundwater pumping, climate conditions, and so on. Additionally, this data allows for the validation of the model by comparing modeled results to real-world observations over the 42.5-year model period. For the purpose of this study, the variety of data and the modular nature of CVHM and MODFLOW is convenient for the construction of model scenarios based upon historical data.

CVHM uses finite-difference approximation to solve the governing equations for groundwater flow, this requires defining the modeled region in terms of discrete units. In CVHM, the Central Valley is represented as a lattice of threedimensionally logically orthogonal cells that forms a grid of two-dimensionally isometric cells at the land surface. Determining the size of these cells represents a certain trade-off: increasing cell size reduces the level of detail in the model while reducing the necessary computer processing power, as well as the amount of data necessary. Reducing cell size has the opposite results. CVHM is discretized at 1-mile increments, meaning that the cells are one mile wide, and nodes are spaced one mile apart. This results in 20,533 active grid cells, organized into 441 rows and 98 columns on the land's surface. The subsurface is represented with 10 layers, with a range of thicknesses from 50 to 400 feet (15.2 to $121.9 \mathrm{~m}$ ), increasing with depth. This thickening of layers with depth allows for a compromise between the need to accurately simulate the groundwater system near the surface and the decreasing availability of data with depth. The total thickness of 1,800 feet $(548.6 \mathrm{~m})$ is to account for the spatial extent of stress on the aquifer from groundwater pumping [3]. The combination of 1-mile $(1.6 \mathrm{~km})$ discretization at the surface and 10 subsurface layers yields a total of 944,518 active three-dimensional cells.

Finite-difference approximation also requires that time be discretized into a 
finite number of "time-steps." Choosing the length of the time-step similarly incurs a trade-off between detail versus processing power and data availability. Since CVHM is designed to model the relatively long-term behavior of the Central Valley's hydrologic system, it is temporally discretized into monthly "stress periods" in which variables like pumping, precipitation, evapotranspiration, and water diversions/deliveries may change. Each stress period is further divided into two time-steps to better simulate the effects of those changes, for a total of 24 time-steps per year.

The MODFLOW-2000 Farm Processes Package (FMP) contributes to the modeling of surface-groundwater interaction largely by dynamically providing estimates for unknowns in the model. One way it does this is by providing evapotranspiration values for both agricultural crops and natural vegetation [1]. For crops, FMP additionally calculates groundwater recharge based off of water demand, irrigation efficiency, and soil type [3]. FMP also codifies land use, including crop types, with values such as root depths, crop coefficients, fraction of surface water runoff, and optimal pressure heads to give rise to modeled estimates for evapotranspiration and deep percolation. Two of these types are "rice" and "idle/fallow", which allows for the experimentation necessary in this study.

CVHM outputs water budget data at each time-step and at the completion of the modeled period, including (but not limited to) total inflow to the aquifer, total outflow from the aquifer, and volume of water stored within the aquifer. However, CVHM does this for the entire Central Valley, so a method was needed to determine the same water budget data for the Sacramento Valley alone. Zonebudget is a tool created by the USGS for MODFLOW, designed for analyzing the water budget within a sub-region of the model. With Zonebudget, one can divide the total model area into sub-regions and determine water budget data for each sub-region, as well as total flows between individual sub-regions. CVHM comes with an existing zone array file that divides the model area into twenty-one California Department of Water Resources water-supply planning areas within each model layer. This file was adjusted to create two zones: one for the Sacramento Valley and a second for the San Joaquin Valley. Zonebudget is then able to use this new file along with water budgets outputs from CVHM to create new water budget outputs for the Sacramento Valley.

\section{Rice Field Idling Scenarios}

While numerous model scenarios were created in the course of experimentation, each begins at a certain baseline. For this baseline, the duration of the model is set to ten years in length. This length was chosen as a compromise between having a sufficiently long duration to determine the effects of experimentation over time, but not so long as to impose an unreasonable cost in time, effort, and computing power. Data for each of these ten years is populated with 2003 water year's data in CVHM. This repetition is to hold non-experimental variables constant year-to-year, so that changes in the model output can be attributed to manipulation of the experimental variable. The 2003 water year in particular was 
chosen because it represents a relatively "normal" year in terms of climate, neither a "wet" year nor a "dry" year. Additionally, 2003 is the last year of input data that was available with CVHM at the time of this study. From this baseline, experimental model scenarios only differ by altering land use within the model, and only by changing model cells designated as rice fields to ones designated as idle/fallow fields.

To characterize the effects of various amounts of idling, model scenarios were created by beginning at the baseline scenario, in which the number of idle fields has not been altered. From there, rice fields are quasi-randomly selected and converted into idle fields in five-percent increments, relative to the baseline number of rice fields, up to a total of fifty-percent. This results in ten model scenarios in addition to the baseline scenario. To characterize the effect of idling over time, two of these groups of ten scenarios were created. In the first group (the "Single-Year Idle" group), increased idling occurred in the first year of the ten-year model period, while the remaining nine years experienced a return to baseline quantities of idling. This was done to isolate the effects of one single aquifer year of idling and examine those effects over time. In the second group ("Continuous Idle" group), an increased percentage of idling was held constant across each of the ten years to examine the cumulative effects of increased idling. This results in a total of twenty model scenarios, plus the baseline scenario (Figure 2).

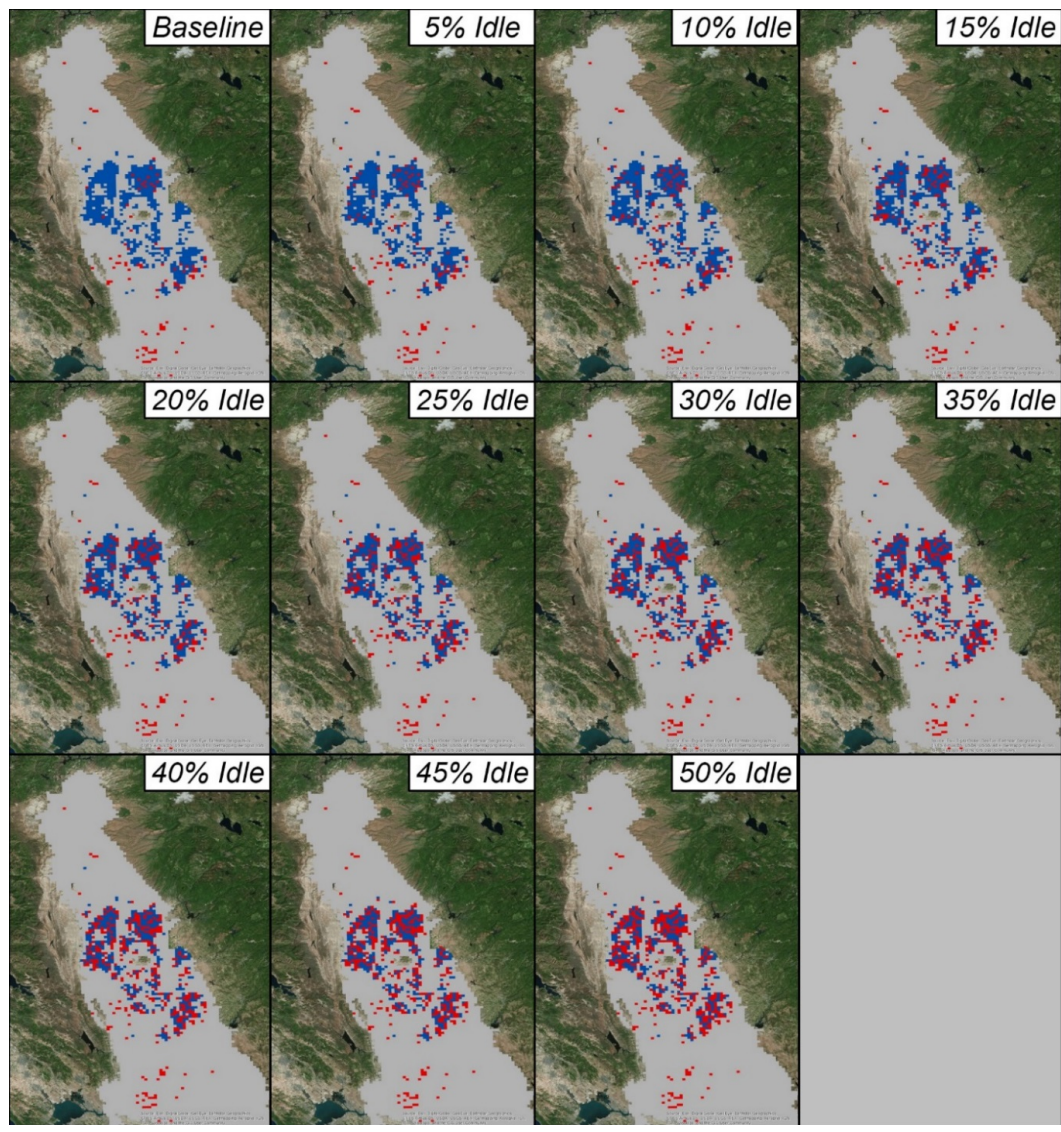

Figure 2. Visualization of active (blue) and idle (red) rice field cells for each modeled scenario. 


\section{Results}

One way in which this study characterizes possible changes in Sacramento Valley aquifers is to examine effects on the total water budget. These water budget outputs, include summaries of storage, inflows and outflows for each time-step. A supplementary MODFLOW tool, GW_Chart, was used to export this data to Microsoft Excel for further analysis. This study aims less to characterize aquifer storage in the experimental scenarios, and more to compare the experimental results with the baseline results. As such, the difference between the experimental aquifer storage values and the unmodified baseline storage values for each experimental scenario are examined and presented.

Each experimental modeled scenario used an altered land-use file with a higher proportion ( $5 \%$ increments) of idle rice fields relative to the baseline scenario. In the single year idle group, these alterations were only applied to the first year of a ten-year model run, while the subsequent nine years remain unmodified. This represents the impact of a single year of additional rice field idling that returns to the baseline activity in the following nine years. The annual effect of each single year idle scenario on groundwater storage is presented in Figure 3.

Between the start of the model period to the first year, aquifer storage declines sharply. Although the decline in the first year may appear to be linear and the expected asymptotic curve is not apparent, this may be because the stress has not been applied long enough to see attenuation in the rate of storage loss. Curvature is apparent after the one-year mark, when the experimental stress ceases, showing a gradual recovery of storage. In each idling scenario, storage did not recover fully by the end of the ten-year model period; in most cases, approximately $60 \%$ to $65 \%$ of storage was recovered relative to its lowest point at the end of first year.

In the continuous idle group, the altered land-use file with a higher proportion (5\% increments) of idle rice fields relative to the baseline scenario were applied on a continuous basis throughout the ten-year model period. The annual effect of each continuous idle scenario on groundwater storage is presented in Figure 4.

Whereas the single year idle group seeks to characterize the effect of the experimental stress in the relative short term, followed by a longer period of recovery, the continuous idle group seeks to characterize the same experimental stress applied over a longer period. Consequentially, the continuous idle group is expressed by a consistent decline in groundwater storage without a period of recovery. One item of note is that the storage curves are still declining at the end of the ten-year model period. Conceptually, the curves should eventually approach an asymptote as the hydrologic system reaches a new equilibrium with the experimental stress, revealing a maximum loss of storage for each experiment. It appears, however, that these equilibria would take longer than ten years to occur and that the maximum losses in storage are not yet apparent.

It is important to understand the temporal distribution of groundwater sto- 


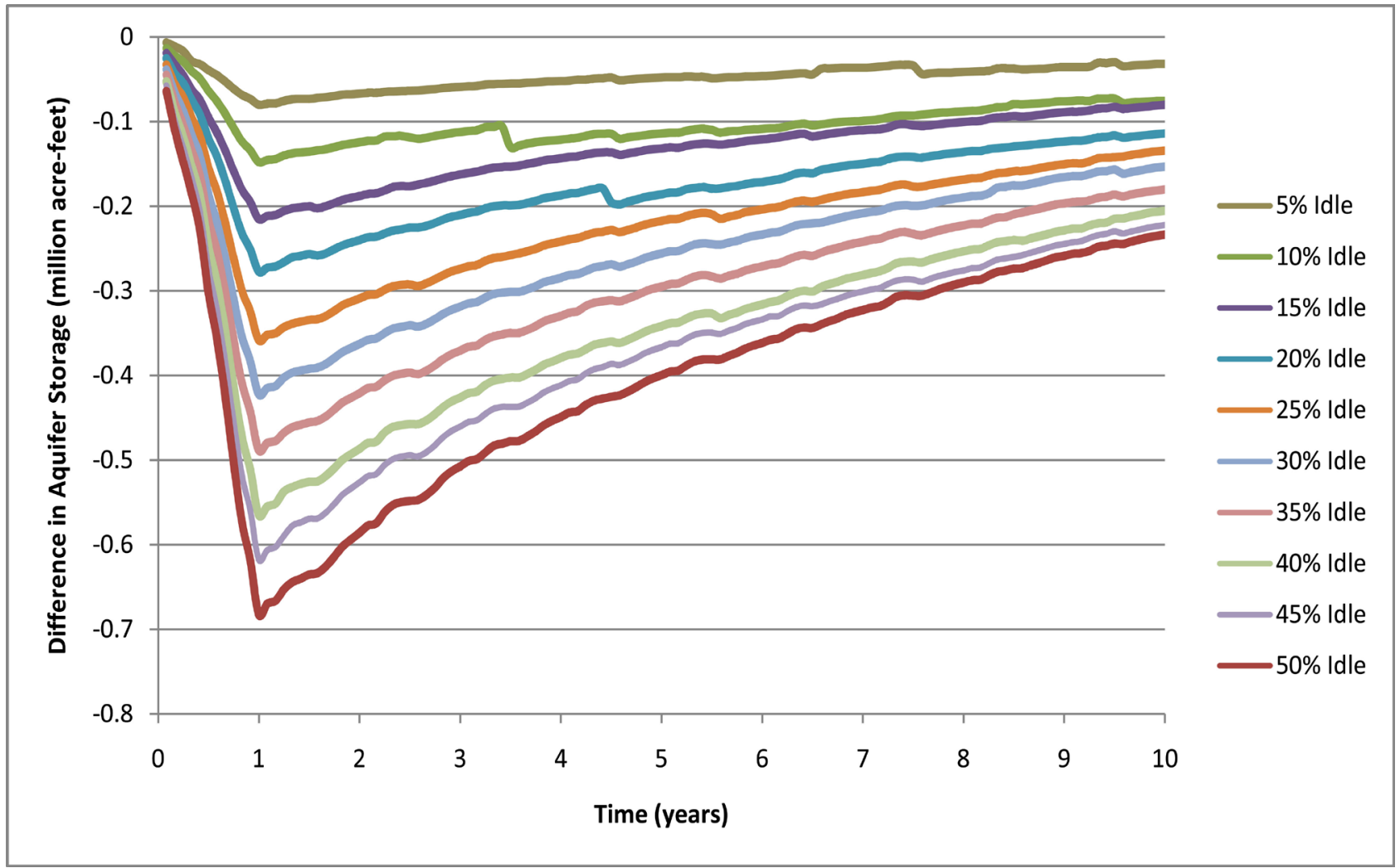

Figure 3. Change in groundwater storage for the single year idle scenario group, normalized.

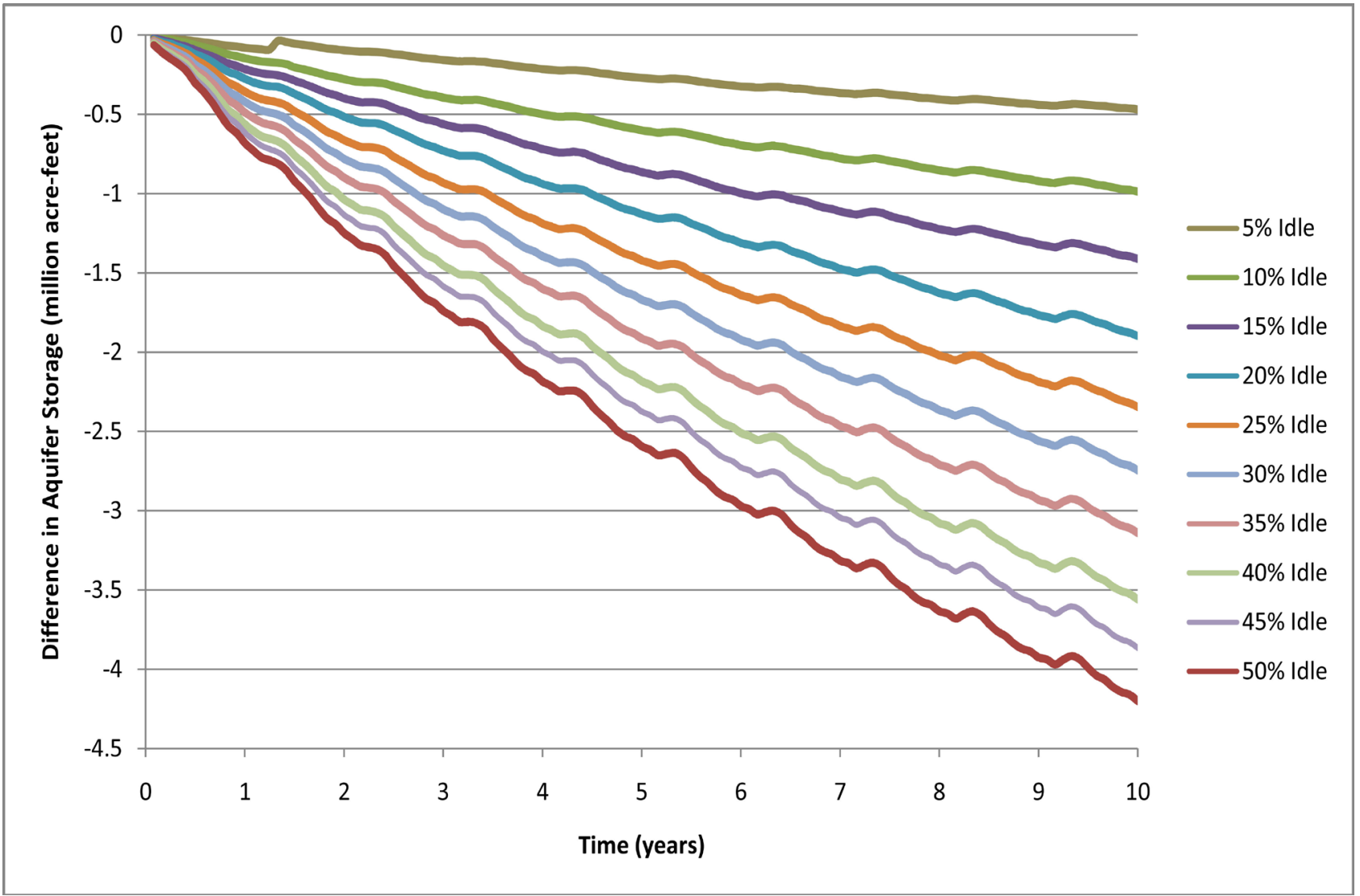

Figure 4. Change in groundwater storage for the continuous idle scenario group, normalized. 
Table 1. Modeled groundwater storage loss for each scenario.

\begin{tabular}{ccc}
\hline \multirow{2}{*}{$\%$ increase in rice field idle } & \multicolumn{2}{c}{ Maximum Storage Loss(acre-feet) } \\
\cline { 2 - 3 } & Single Year Scenario & Continuous Scenario \\
\hline $5 \%$ & 79,984 & 468,400 \\
$10 \%$ & 147,655 & 987,970 \\
$15 \%$ & 215,061 & $1,410,940$ \\
$20 \%$ & 277,208 & $1,897,746$ \\
$25 \%$ & 358,030 & $2,344,941$ \\
$30 \%$ & 422,106 & $2,744,552$ \\
$35 \%$ & 488,279 & $3,319,726$ \\
$40 \%$ & 564,632 & $3,558,334$ \\
$45 \%$ & 617,377 & $3,864,265$ \\
$50 \%$ & 682,230 & $4,197,788$ \\
\hline
\end{tabular}

rage losses that are presented in Figure 3 and Figure 4, but it is also important to specifically identify the maximum storage losses under each scenario (Table 1). In the case of the single year idle scenarios the maximum storage loss occurred at the end of year 1 while the maximum storage losses for the continuous idle scenarios occurred at the end of year 10.

To provide some perspective, the magnitudes of maximum storage loss for some of the single year scenarios can be compared to the capacity of some of California's surface water reservoirs, such as Englebright Lake (70,000 acre-feet; comparable to the $5 \%$ single year idle scenario) or Isabella Lake $(568,000$ acre-feet; comparable to the $40 \%$ single year idle scenario). The magnitude of maximum storage loss increases as the proportion of single year idle rice fields increases, with a roughly linear relationship. Each five-percent increase in single year idling corresponds to a mean of about 67,000 acre-feet of additional aquifer storage loss, with an average deviation from the mean of 5500 acre-feet. The magnitudes of storage loss at the end of the ten-year continuous idle scenarios can also be compared to the capacity of some of California's surface water reservoirs, such as Camache Reservoir (417,120 acre-feet; comparable to the 5\% continuous idle scenario) or Oroville Lake (3,537,577 acre-feet; comparable to the $40 \%$ continuous idle scenario).

\section{Conclusion}

Simulated water storage values indicate that rice field idling can have a sizably negative effect on available groundwater storage in the Sacramento Valley. The temporal distribution of these effects are compounded over time as rice field idling continues, and aquifer storage is found to gradually recover after idling ceases. Spatially, the effects range from being very acute in areas with a high density of idle rice fields, to being negligible in areas that are distal to idle rice fields. These relationships should be useful in evaluating cropland idling water transfers from a hydrologic standpoint. Similarly, these results may be informa- 
tive to other policies and strategies that relate to regional groundwater management. For example, the simulated groundwater storage losses caused by idled rice fields imply a corresponding amount of recharge from active rice fields. Given this, the percolation of irrigation water in rice fields might be incorporated into a strategy for managed aquifer recharge and overall sustainable groundwater management. Although this work focused on rice field idling in the Sacramento Valley, the same methods could be applied to other regions of California.

\section{Limitations/Future Work}

Judgments based on this study's results, beyond those described above, are likely outside the scope of this study. It is important to bear in mind the conditions within the model used in this experiment. First, while modeled conditions are based on historical data, these conditions were deliberately manipulated to remove extraneous variables to the extent reasonable to isolate the effects of rice field idling. No attempts were made to accurately reflect present circumstances, or forecast future outcomes. Second, as a consequence of the scale of the model, many of the variables are generalized. Due to spatial discretization, each onemile by one-mile cell is treated as a homogenous unit. Additionally, variables such as crop coefficients have uniform values for each type of crop or vegetation. As a result, one is cautioned against looking beyond the experimental results as a representation of the entire Sacramento Valley region and attempting to find accurate and precise results for smaller areas within the region.

Given the large scale of the model and the generalization of land use and crop coefficients, the assignment of idled rice field cells may have unintended consequences on the experimental results. For this study the rice field cells were changed to idle cells quasi-randomly to avoid bias in selecting those cells manually. In the context of the model, where crop coefficients are uniform, this is not problematic. In reality, however, which rice fields are idled might be determined in a systematic way, deliberately or otherwise. For example, some rice fields may be more efficient than others. If a farmer is aware of this, they might selectively idle their least hydrologically efficient fields (that is, the fields in which they need to apply the most water to produce the same crop yield). In such a case, the model may underestimate the effect of rice field idling, since the fields idled would be the ones that require the most water and therefore might have the most water percolating into the groundwater system.

While there are many possible avenues of future study, perhaps the most important is to perform similar experiments using climate data from a "dry" year. Arelatively "normal" climate year was chosen for this experiment for the sake of examining the effects of rice field idling in typical conditions. However, since water transfers are more common when water is scarce, further experimentation to examine the effects of rice field idling during one or more "dry" years would seem worthwhile. Such experimentation might include the effects of multiple consecutive years of dry conditions, or the effects of a single year or a few years 
of dry conditions.

\section{Acknowledgements}

Partial funding for this project has been provided by the California State University Agricultural Research Institute (ARI) and the National Institute of Food and Agriculture (NIFA) U.S. Department of Agriculture award number 2015-7000123549. Any opinions, findings, conclusions, or recommendations expressed in this publication are those of the authors and do not necessarily reflect the view of the U.S. Department of Agriculture.

\section{References}

[1] Bay Delta Conservation Plan (2015) California Department of Water Resources and U.S. Bureau of Reclamation, Public Review Partially Recirculated Draft Environmental Impact Report/Supplemental Draft Environmental Impact Statement (RDEIR/SDEIS).

http://baydeltaconservationplan.com/2015PublicReview/PublicReviewRDEIRSDEIS /PublicReviewRDEIRSDEIS_Links.aspx

[2] Plant and Soil Sciences eLibrary (2016) Chapter 8, Irrigation Efficiencies, University of Nebraska, Lincoln.

http://croptechnology.unl.edu/pages/informationmodule.php?idinformationmodul $\mathrm{e}=1130447123 \&$ topicorder $=8 \& \operatorname{maxto}=73 \& \operatorname{minto}=1$

[3] Faunt, C.C. (2009) Groundwater Availability of the Central Valley Aquifer, California: U.S. Geological Survey Professional Paper 1766.

[4] California Environmental Protection Agency, State Water Resources Control Board (2015) The Water Rights Process.

http://www.waterboards.ca.gov/waterrights/board_info/water_rights_process.shtml \#rights

[5] California Environmental Protection Agency, State Water Resources Control Board (2015) State Water Resources Control Board Water Transfer Program Information. http://www.waterboards.ca.gov/waterrights/water_issues/programs/water_transfers /docs/transproginfo.pdf

[6] California Department of Water Resources and U.S. Bureau of Reclamation Mid-Pacific Region (2014) Draft Technical Information for Preparing Water Transfer Proposals (Water Transfer White Paper), Information for Parties Preparing Proposals for Water Transfers Requiring Department of Water Resources or Bureau of Reclamation Approval. http://water.ca.gov/watertransfers/docs/2015_Water_Transfer_White_Paper.pdf

[7] Houk, E. (2016) The Contribution of Agriculture to Northeastern California's Economy. California State University, Chico Agribusiness Institute Report. https://www.csuchico.edu/ag/about/agribusiness-institute/ag-economy-2014.pdf

[8] Hafeez, M.M., Bouman, B.A.M, Van de Giesen, N. and Vlek, P. (2007) Scale Effects on Water Use and Water Productivity in a Rice-Based Irrigation System (UPRIIS) in the Philippines. Agricultural Water Management, 92, 81-89.

[9] Hanson, R.T., Schmid, W., Faunt, C.C. and Lockwood, B. (2010) Simulation and Analysis of Conjunctive Use with MODFLOW's Farm Process. Ground Water, 48, 674-689. https://doi.org/10.1111/j.1745-6584.2010.00730.x

[10] Scanlon, B.R., Faunt, C.C., Longuevergne, L., Reedy, R.C., Alley, W.M., McGuire, V.L. and McMahon, P.B. (2012) Groundwater depletion and sustainability of irriga- 
tion in the US High Plains and Central Valley. Proceedings of the National Academy of Sciences, 109, 9320-9325. https://doi.org/10.1073/pnas.1200311109

[11] Scanlon, B.R., Longuevergne, L. and Long, D. (2012) Ground Referencing GRACE Satellite Estimates of Groundwater Storage Changes in the California Central Valley, USA. Water Resource Research, 48, W04520.

https://doi.org/10.1029/2011WR011312

\section{Scientific Research Publishing}

Submit or recommend next manuscript to SCIRP and we will provide best service for you:

Accepting pre-submission inquiries through Email, Facebook, LinkedIn, Twitter, etc. A wide selection of journals (inclusive of 9 subjects, more than 200 journals)

Providing 24-hour high-quality service

User-friendly online submission system

Fair and swift peer-review system

Efficient typesetting and proofreading procedure

Display of the result of downloads and visits, as well as the number of cited articles Maximum dissemination of your research work

Submit your manuscript at: http://papersubmission.scirp.org/

Or contact jwarp@scirp.org 